\title{
INVESTIGATION OF BIOFILM FORMATION IN COAGULASE-NEGATIVE STAPHYLOCOCCI ISOLATED FROM PLATELET CONCENTRATE BAGS
}

Rosiéli MARTINI(1), Rosmari HÖRNER(1), Roberta Filipini RAMPELOTTO(1), Litiérri Razia Litiérri GARZON(1), Melise Silveira NUNES(1), Mayza Dalcin TEIXEIRA(2) \& Daniel Ângelo Sganzerla GRAICHEN(2)

\begin{abstract}
SUMMARY
Platelet Concentrates (PCs) are the blood components with the highest rate of bacterial contamination, and coagulase-negative staphylococci (CoNS) are the most frequently isolated contaminants. This study investigated the biofilm formation of 16 contaminated units out of 691 PCs tested by phenotypic and genotypic methods. Adhesion in Borosilicate Tube (ABT) and Congo Red Agar (CRA) tests were used to assess the presence of biofilm. The presence of icaADC genes was assessed by means of the Polymerase Chain Reaction (PCR) technique. With Vitek ${ }^{2}$, Staphylococcus haemolyticus was considered the most prevalent CoNS (31.25\%). The CRA characterized $43.8 \%$ as probable biofilm producers, and for the ABT test, 37.5\%. The icaADC genes were identified in seven samples by the PCR. The ABT technique showed $85.7 \%$ sensitivity and $100 \%$ specificity when compared to the reference method (PCR), and presented strong agreement $(\mathrm{k}=0.8)$. This study shows that species identified as PCs contaminants are considered inhabitants of the normal skin flora and they might become important pathogens. The results also lead to the recommendation of ABT use in laboratory routine for detecting biofilm in CoNS contaminants of PCs.
\end{abstract}

KEYWORDS: Biofilm; Staphylococci; Platelet Concentrates; Transfusion; Microbiology.

\section{INTRODUCTION}

Platelet Concentrates (PCs) are blood components widely used in patients with neoplastic diseases, who are undergoing chemotherapy, as a way to reduce the risk of bleeding ${ }^{1}$. However, such components are the ones with the highest rate of bacterial contamination, being considered responsible for almost all of the septic transfusion reactions ${ }^{2}$.

According to the Brazilian Ministry of Health, approximately 3.5 million blood donations are made ${ }^{3}$ per year in Brazil. The Brazilian Hemotherapy Service consists of a vast network that offers about 2,332 units providing services ${ }^{4}$. This scenario reveals the great national physical infrastructure necessary to meet the demand for blood components in the country. While Gram-positive bacteria (GP) are responsible for the highest rates of contamination in PCs $(60 \%)$, the less frequent Gramnegative (GN) may present the greatest number of fatal septic reactions ${ }^{5}$. Among GP, coagulase-negative staphylococci (CoNS) stand out, and Staphylococcus epidermidis is the most frequently involved species ${ }^{6,7}$; and their capacity to adhere to polymer surfaces and consequent biofilm production are virulence factors of this species ${ }^{8}$.

In recent years, CoNS have emerged as an important nosocomial pathogen, especially in immunocompromised patients, due to their ease in incorporating different resistant to antimicrobial genes, favored by the biofilm environment in the exchange of genetic material. This virulence factor has been considered one of the most significant risks to patients. The difficulty of a clinical treatment for infections associated with biofilms has direct and indirect consequences (longer hospitalization, cost of antibiotics and complementary medicines, and diagnostic procedures) on the patient's outcome and quality of life $\mathrm{e}^{9-11}$.

Biofilm is defined as a sessile microbial community surrounded by a polymeric extracellular matrix produced by the bacteria ${ }^{12}$. An important component in biofilm accumulation of $S$. epidermidis is the polysaccharide intercellular adhesin (PIA) and its production is mediated by the gene ica (intercellular gene cluster adhesion), an operon that contains the ica RADBC ${ }^{13-16}$, four biosynthetic genes (icaADBC), and one regulation gene (icaR). The PIA is a linear homopolymer composed by approximately 130 residues of $\mathrm{N}$-acetylglucosamine connected by $\beta-1$, 6 links, of which 15 to $20 \%$ are deacetylated ${ }^{14}$.

The enzymes IcaA and IcaD, when co-expressed, will show better activity for the assemblage of $\beta(1-6)$-linked glucosaminoglycans that comprise PIA. The absence of IcaD is associated with a decrease in PIA production ${ }^{17}$, the likely IcaC functions in the extrusion of PIA from the bacterial cell ${ }^{18}$, whereas the IcaB appears to function as a

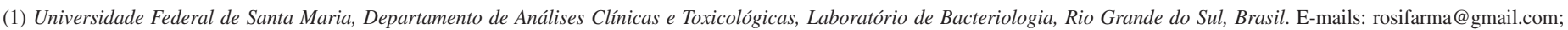
rosmari.ufsm@gmail.com; robertarampelotto@gmail.com; liti_razia@msn.com; melisenunes@ hotmail.com

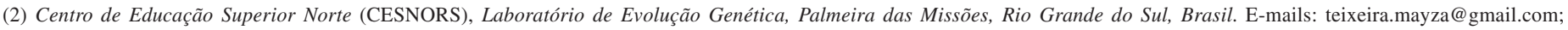
das.graichen@ufsm.br

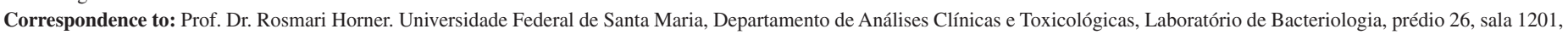
Campus da UFSM. 97015-900 Santa Maria, RS, Brasil. Tel. (55) 3220-8751. E-mail: rosmari.ufsm@ gmail.com 


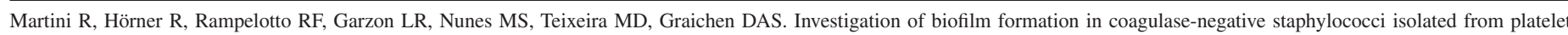
concentrate bags. Rev Inst Med Trop Sao Paulo. 2016;58:1.

deacetylase ${ }^{19}$. Although the expression of the icaA gene might promote a low production of PIA, the expression of icaAD or icaADC genes stimulates an increased production of biofilm ${ }^{17,20-22}$. Many factors influence the biofilm formation under physiological conditions. It is known that biofilm formation is subject to environmental conditions such as sub-inhibitory concentrations of antimicrobials, temperature rise, anaerobiosis, osmolarity, thus leading to the changing between positive and negative phenotypes of biofilm ${ }^{13}$.

Some studies have reported that several genes are directly or indirectly involved in the molecular mechanisms of biofilm formation in $S$. epidermidis, and the most outstanding are the at $\mathrm{E}$ gene which encodes the AtlE autolysin that is responsible for the ability to directly connect to the polymeric surface ${ }^{23}$; the $a g r$ gene, which controls biofilm formation, whose non-functionality facilitates the primary attachment of the pathogen to the surface ${ }^{24}$; the $\operatorname{luxS}$ gene, with a significant impact on biofilm formation, and whose deletion leads to an increase in the transcription regulation of icaADBC, resulting in an increase in the PIA synthesis ${ }^{25,26}$; and the $i c a \mathrm{R}$ gene, which is very important for biofilm formation, as it is considered a negative transcription regulator of icaADBC, essential for the production of PIA ${ }^{21}$. Besides these genes, the proteins Aap (accumulation-associated protein) ${ }^{10}$ and Bap (biofilmassociated protein) ${ }^{27}$ are directly associated with biofilm formation. Therefore, it becomes increasingly clear that the potential virulence of a bacterium does not depend exclusively on a single factor.

Biofilms are highly hydrated structures containing channels that allow the internal diffusion of nutrients and oxygen, and their formation protects against the innate defense mechanisms of the host and the influx of antimicrobials, hindering drug diffusion in tissues ${ }^{28}$, thus facilitating the development of chronic infections ${ }^{29}$. It is a consensus in literature that ica $\mathrm{A}, \mathrm{C}$ and $\mathrm{D}$ genes are responsible for encoding biofilm-forming enzymes, evidenced in most $\mathrm{CoNS}^{8,30}$.

This study assessed 16 bacteria isolated from 691 bags of PCs from the Blood Bank of the city of Santa Maria, Rio Grande do Sul State (HEMORGS/SM, RS), in order to detect biofilm formation in these contaminants, by means of phenotypic and genotypic methods.

\section{MATERIALS AND METHODS}

Inclusion criteria for bacterial isolates: A total of $691 \mathrm{PCs}$ were analyzed, considering that 665 were obtained by centrifugation of whole blood and 26 by apheresis. All samples were collected at HEMORGS between 2009 and 2010, and the cultures were prepared from the tubular portion of the bags of platelets. After collection, the samples were sent to the Laboratory of Bacteriology, Department of Clinical and Toxicological Analysis of the Health Sciences Center of the Universidade Federal de Santa Maria (UFSM). The tests for detection of bacterial contamination in PCs were performed in a type II biosafety cabinet, totally exhausted. Sterilization of the tubular portion of the bags of PCs was performed with $70 \%$ alcohol for approximately one minute. Bacterial investigation of these PCs bags is described in detail by MARTINI et al..$^{31}$.

Since the opening of HEMORGS - Santa Maria in May 2008, bacteriological control has been conducted in whole blood-derived platelets (10 monthly samples) and apheresis platelets (10 monthly samples) ${ }^{32}$. The technique used for routine bacteriological screening at HEMORGS is described by CUNHA et al. $^{33}$ : approximately 300 microliters $(\mu \mathrm{L})$ are removed from the platelet bag tubing, cultured in 2 milliliters $(\mathrm{mL})$ of Mueller Hinton broth (MHB), and incubated at 35 $\pm 2{ }^{\circ} \mathrm{C}$. After five days of incubation, $10 \mu \mathrm{L}$ of the broth containing the PC sample were sub-cultured in sheep blood agar 5\% (BA), and the plates were incubated in the same conditions. The samples that showed bacterial growth within 24-48 hours (h) were subcultured from initial MHB to new plates of BA, and incubated in the same conditions, in order to exclude false positives. The samples were considered "true positives" after the culture repetition and confirmation with the isolation of bacteria obtained from the first culture ${ }^{31}$. This quality control follows the standards recommended by the legislation, which does not propose the culture of all samples as pre-transfusion screening, but of at least $1 \%$ of the monthly production or 10 units per month ${ }^{34,35}$.

Currently, the Ordinance No. 2.712 of November 12, 2013, redefines the technical regulation for hemotherapeutic procedures. It describes that the bacteriological control of PCs remains the same as reported by the current Resolution of the Collegiate Board of Directors (RDC) No. 57 of December 16, 2010, as well as the previous RDC No. 153 of June 14, $2004^{34,35}$. Nevertheless, with the inclusion of the paragraph $8(\S 8)$ of Article 116, which describes that "Pelo alto risco de contaminação microbiológica dos concentrados de plaquetas pela sua condição de armazenamento, recomenda-se realização de avaliação de contaminação microbiológica em $100 \%$ desta produção", or "Due to the high risk of microbiological contamination of platelet concentrates regarding their storage conditions, it is recommended to perform the microbiological contamination assessment on $100 \%$ of this production" 36 .

Assays for bacterial detection in PCs (31): The qualitative assay was performed on 612 samples, according to CUNHA et al. ${ }^{33}$. Samples that did not show any bacterial growth on BA in 48 hours were considered negative. The ones that showed development of Colony-Forming Units (CFU) were considered positive, and a new subculture was performed to exclude any possible contamination.

The quantitative assay was performed on 292 samples, as described by YOMTOVIAN et al. ${ }^{37}$. The samples that showed bacterial growth regardless of the number of colonies developed were considered positive; the multiplication factor ten was used to obtain the number of CFU/mL.

Both the qualitative ${ }^{33}$ and the quantitative ${ }^{37}$ techniques were used in 79 samples, with some modifications, and named Teste do Crescimento Diário (Daily Growth Test). At every $24 \mathrm{~h}$ of incubation in MHB, $10 \mu \mathrm{L}$ of the broth containing the sample were subcultured in BA, with an automatic pipette, and plates were incubated in a bacteriological incubator $\left(35 \pm 2{ }^{\circ} \mathrm{C}\right.$ with $5 \%$ of $\mathrm{CO}_{2}$ for $\left.24-48 \mathrm{~h}\right)$. Subsequent sowings were performed, at $24 \mathrm{~h}$ intervals for each analysis. Four sowings were performed altogether, and readings taken at 24, 48, 72 and $96 \mathrm{~h}$ after the first incubation. The samples that showed no colony growth in 48 $\mathrm{h}$ were considered negative, and the ones with growth were considered positive. All cultures were performed in duplicate tests, with the purpose of excluding any possible contamination during treatment.

Bacterial isolates of the 691 PCs: A total of 16 isolates of CoNS were obtained through an investigation of bacterial contamination in 691 


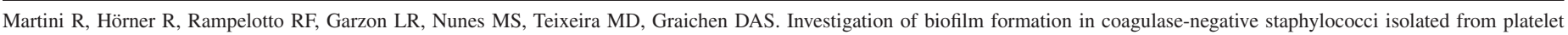
concentrate bags. Rev Inst Med Trop Sao Paulo. 2016;58:1.

bags of PCs, which constituted the research sample of this study. The following international reference standard strains (American Type Culture Collection-ATCC) were used as controls in the genotypic and phenotypic tests: Staphylococcus epidermidis ATCC 12228 negative control biofilm and Staphylococcus epidermidis ATCC 35984 positive control.

Phenotypic identification: The isolates were tested for phenotypic identification through automation, with Vitek® 2 (bioMérieux, Marcy L'Étoile, France), and the technique was performed in duplicate.

Sample preparation: In order to perform the phenotypic tests, the strains stored in Trypticase Soy Broth plus $15 \%$ of glycerol were subcultured in petri dishes containing Mueller Hinton agar, and incubated at $35 \pm 2{ }^{\circ} \mathrm{C}$ for $24 \mathrm{~h}$. For the genotypic test, the process of extraction of deoxyribonucleic acid (DNA) was performed by a thermal analysis procedure ${ }^{38-41}$. Besides, it should be noted that the subsequent tests were performed in duplicate.

Amplification of the gene 16S of ribosomal RNA (RNAr): After extraction, each sample was submitted to electrophoresis in $1.0 \%$ agarose gel to verify the presence of DNA in the extracted material. The 16S rRNA was amplified by the Polymerase Chain Reaction (PCR).

\section{Phenotypic methods for the research of biofilm production}

Adhesion in borosilicate tube (ABT): This assay was performed as according to CHRISTENSEN et $a l^{42}$. Positivity was indicated by the presence of a layer of stained material adhered to the inner wall of the tubes.

Congo red agar (CRA): The test was carried out according to FREEMAN et al. $^{43}$. The plates of CRA were inoculated and incubated at ambient temperature for $24 \mathrm{~h}$, at $35 \pm 2{ }^{\circ} \mathrm{C}$. It was positive (biofilmproducing) when black colonies were observed, with shiny or dry/opaque aspect. On the other hand, non-biofilm producers formed pink $(\mathrm{P})$, red (R) or burgundy (B) colonies.

Genotypic method for the research of biofilm production: In order to determine the genes ica $\mathrm{A}$, ica $\mathrm{C}$ and $i c a \mathrm{D}$, the following pairs of primers were used: icaA_F-ACAGTCGCTACGAAAAGA AA and $i c a$ A_R-GGAAATGCCATAATGAGAAC; $i c a$ C_FTAACTTTAGGCGCATATGTTT and icaC_R-TTCCAG TTAGGCTGGTATTG; icaD_FATGGTCAAGCCCAGACAGAG and icaD_RCGTGTTTTCAACATTTAATGCAA (Ludwig Biotec $®$ ). The sequence of primers and the technique followed the instructions of ARCIOLA et al. ${ }^{44}$. A sample was considered biofilm-producing when the presence of genes icaAD or icaADC was detected. When only one of these genes was found, the sample was considered negative for the production of biofilm ${ }^{8}$.

Statistical analysis: The assessment of sensitivity and specificity was based on the comparison between the phenotypic methods tested with the PCR technique, which was considered a standard. The Kappa index (k) was also calculated in order to verify the agreement between the results obtained by the different methods $s^{8,44,45}$.

Ethical considerations: This study was approved by the Research Ethics Committee (CEP) of UFSM, under the number 0285.0.243.000-09.

\section{RESULTS}

A total of 16 isolates of CoNS were obtained through an investigation of bacterial contamination in 691 PCs from HEMORGS: 5 Staphylococcus haemolyticus (31.25\%), 4 Staphylococcus epidermidis (25\%), 4 Staphylococcus warneri (25\%) and 3 Staphylococcus saprophyticus (18.75\%). The bacterial species isolated from contaminated PCs bags were identified by the automated system Vitek® 2, described in Figure 1.

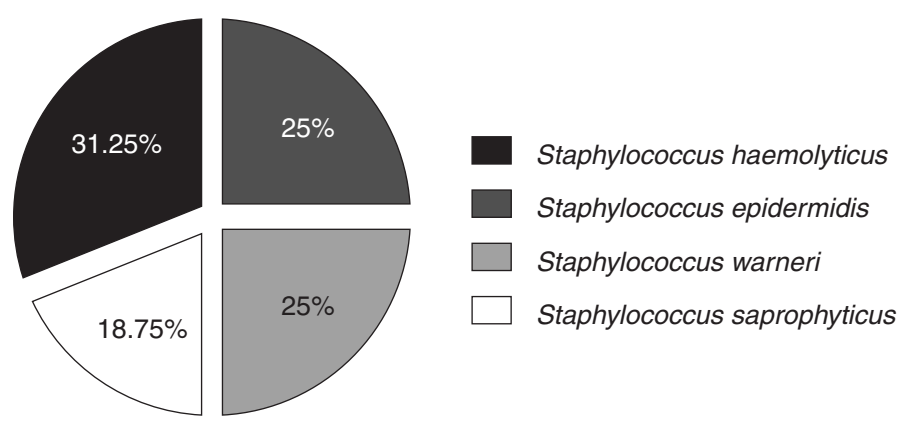

Fig. 1 - Distribution of the 16 species of coagulase-negative staphylococci isolated from 691 Platelet Concentrate bags.

Through research for the gene $16 \mathrm{~S}$ of ribosomal RNA (rRNA-) in the samples of this study, we found that they all had great quality of extracted DNA, thus allowing the investigation of single genes. The research of the biofilm, performed with CRA, was positive in seven $(43.75 \%)$ out of the 16 samples of CoNS, with the black color of the colonies evidencing probable biofilm-producing bacteria. The other strains showed other colors ( $\mathrm{B}$ and $\mathrm{R}$ ), indicating the absence of biofilm production. With the ABT technique, six samples (37.5\%) were characterized as adherent, in other words, probable biofilm producers (Table 1).

The genotypic analysis, carried out by PCR, investigated the presence of genes ica A, C, and D, so we considered probable biofilm-forming the samples in which the genes icaAD or ica $\mathrm{ADC}^{8}$ were found. The result of this analysis is detailed in Table 1 . Seven out of the 16 samples $(43.75 \%)$ presented the genes ica $\mathrm{AD}$ and/or ica $\mathrm{ADC}$, concomitantly.

Comparing the results of this study, the phenotypic method of ABT and the genotypic method in biofilm production, $85.7 \%$ sensitivity and $100 \%$ specificity were obtained, showing high agreement $(\mathrm{k}=0.87)$. When CRA and PCR techniques were compared, $71 \%$ of sensitivity and $78 \%$ of specificity were obtained. We also verified an agreement index $\mathrm{k}=0.49$, considering the PCR as the standard method.

\section{DISCUSSION}

In our study, all organisms isolated in the samples of contaminated PCs were also CoNS, similar to the results found by other authors ${ }^{46-48}$. However, no contamination was identified by GN bacteria, different from the findings of CUNHA et al. ${ }^{33}$, in which $62.5 \%$ of the PCs were contaminated by GN bacteria and $37.5 \%$ by GP Regarding bacterial species, there was a predominance of Staphylococcus haemolyticus (31.25\%), followed by Staphylococcus epidermidis and Staphylococcus warneri at a rate of $25.0 \%$ each. 
Martini R, Hörner R, Rampelotto RF, Garzon LR, Nunes MS, Teixeira MD, Graichen DAS. Investigation of biofilm formation in coagulase-negative staphylococci isolated from platelet concentrate bags. Rev Inst Med Trop Sao Paulo. 2016;58:1.

Table 1

Results regarding the research of genes ica A, C and D in the 16 samples of coagulase-negative staphylococci isolates from Platelet Concentrates, by the Polymerase Chain Reaction technique and the phenotypic tests for biofilm production.

\begin{tabular}{|c|c|c|c|c|c|c|c|c|}
\hline \multirow{2}{*}{ Samples } & \multirow{2}{*}{ Species } & \multicolumn{3}{|c|}{ Genes } & \multicolumn{2}{|c|}{ Biofilm-positive } & \multicolumn{2}{|c|}{ Slime Production } \\
\hline & & $i c a \mathbf{A}$ & $i c a \mathrm{C}$ & icaD & icaAD & icaADC & CRA & ABT \\
\hline 1 & S. epidermidis & + & + & + & + & + & - & + \\
\hline 2 & S. epidermidis & + & + & + & + & + & + & + \\
\hline 3 & S. saprophyticus & + & + & + & + & + & + & + \\
\hline 4 & S. haemolyticus & - & + & - & - & - & + & - \\
\hline 5 & S. saprophyticus & - & - & - & - & - & - & - \\
\hline 6 & S. haemolyticus & + & + & + & + & + & + & - \\
\hline 7 & S. saprophyticus & - & - & - & - & - & - & - \\
\hline 8 & S. epidermidis & - & - & - & - & - & - & - \\
\hline 9 & S. warneri & - & - & - & - & - & - & - \\
\hline 10 & S. haemolyticus & - & + & - & - & - & + & - \\
\hline 11 & S. haemolyticus & + & + & + & + & + & + & + \\
\hline 12 & S. warneri & - & - & - & - & - & - & - \\
\hline 13 & S. haemolyticus & + & + & + & + & + & + & + \\
\hline 14 & S. epidermidis & - & - & - & - & - & - & - \\
\hline 15 & S. warneri & - & - & - & - & - & - & - \\
\hline 16 & S. warneri & + & + & + & + & + & - & + \\
\hline
\end{tabular}

$\mathrm{CRA}=$ Congo red agar; $\mathrm{ABT}=$ Adhesion in borosilicate tube; ““" = absence; “+” = presence

A study by $\mathrm{GRECO}^{49}$ reported that 13 contaminant CoNS strains were isolated during a routine screening of PCs by Canadian Blood Services, between January 2006 and May 2007, being S. epidermidis (53.8\%) the predominant species, followed by $S$. capitis and $S$. hominis, $15.4 \%$ each. Moreover, ROOD et al..$^{50}$ described that $35.8 \%$ of contamination in PCs was caused by S. epidermidis, $17.9 \%$ by S. capitis and $14.9 \%$ by $S$. saccharolyticus. The species $S$. haemolyticus was not reported in these two recent studies, however, the only Brazilian study regarding bacterial contamination of PCs demonstrated that $S$. haemolyticus and S. hominis have been responsible for an individual rate of $12.5 \%$ of bacterial contamination ${ }^{33}$.

CoNS are natural colonizers of human skin and mucosa. However, they have recently been acknowledged as important nosocomial pathogens due to their ability to form biofilm ${ }^{18}$. Currently, the increase of antibiotic resistance in some clinical isolates may be related to their ability to form biofilm, because the acquisition of some resistance traits is possible within biofilm, through gene transfer ${ }^{51}$.

S. epidermidis are the most isolated ${ }^{52}$ from blood cultures among CoNS, S. haemolyticus being the second most, and $S$. haemolyticus have the highest rates of resistance to antimicrobials ${ }^{53}$. This species can cause septicemia, peritonitis, otitis and urinary tract infections. S. epidermidis and S. haemolyticus are opportunistic human pathogens, and difficult to be eradicated because of their resistance to antibiotics ${ }^{52}$. In contrast to $S$. epidermidis, the molecular basis of virulence of $S$. haemolyticus is in general largely unknown; however, biofilm formation is a common clinical phenotype ${ }^{54}$. Furthermore, $S$. haemolyticus have the highest level of antimicrobial resistance of all CoNS and their heteroresistance to glycopeptides ${ }^{53}$ is very common. Thus, it limits the therapeutic options and makes an $S$. haemolyticus infection a serious threat ${ }^{54}$. Therefore, the presence of bacterial contaminants in PCs such as $S$. epidermidis and $S$. haemolyticus, considered potentially resistant, generates a major concern due to the virulence of these strains, being directly linked to their ability to cause septic transfusion reactions and influence the clinical outcome of the receiver.

Regarding the detection values obtained in this study for the CRA method, results similar to ours have been reported by ARCIOLA et al., CAFISO et al. and LAZZARATTO et al.; GRECO found $57.5 \%$, $57 \%, 37.5 \%, 54 \%$ and $30.8 \%$, respectively ${ }^{13,44,49,55,56}$. RÚZICKA et al. detected $43.5 \%$ of biofilm production in S. epidermidis isolated from blood cultures and $21.1 \%$ of isolates of skin. However, another research performed by OLIVEIRA \& CUNHA, in another Brazilian state, demonstrated that $73 \%$ of the CoNS were producers of biofilm when subcultured in CRA. For the ABT test, RÚZICKA et al. found $53.7 \%$ and $22.4 \%$ in blood cultures and skin, respectively. OLIVEIRA \& CUNHA also reported a higher rate for ABT, $82 \%{ }^{8,57}$.

The results obtained by PCR are similar to the ones found by CAFISO et al., who detected the genes ica $\mathrm{AD}$ and ica $\mathrm{ADC}$ in $45 \%$ of the isolates. ARCIOLA et al. reported the presence of the same genes in $59 \%$ of the samples. OLIVEIRA \& CUNHA found $82 \%$ of genes icaAD and icaADC and GRECO, $23.1 \%$ of $i c a \mathrm{D}^{8,13,44,49}$. 
Martini R, Hörner R, Rampelotto RF, Garzon LR, Nunes MS, Teixeira MD, Graichen DAS. Investigation of biofilm formation in coagulase-negative staphylococci isolated from platelet concentrate bags. Rev Inst Med Trop Sao Paulo. 2016;58:1.

In a recent study, ALI et al..$^{30}$, while studying $S$. epidermidis isolated from contaminated PCs bags, reported its ability to convert to a positive phenotype of biofilm when cultured under similar conditions to the PCs bags, with or without the presence of the ica genes. It happens because S. epidermidis are able to form biofilms that adhere to the plastic of platelet storage bags and platelet aggregates' as already reported by GRECO-STEWART et al. in strains of Serratia marcescens ${ }^{58}$. Bacteria with slower growth create a larger amount of biofilm, which makes their detection more difficult in automated culture media ${ }^{30}$.

According to the literature, the rates of $100 \%$ sensitivity and specificity are found with ABT, and $89 \%$ sensitivity and $100 \%$ specificity with CRA, when comparing to $\mathrm{PCR}^{8}$. For the CRA test, GRECO reports $100 \%$ of sensitivity and $90 \%$ of specificity ${ }^{49}$. In our study, the ABT method was the phenotypic test with a better performance than CRA in biofilm detection, a result in agreement with OLIVEIRA \& CUNHA ${ }^{8}$.

Positive samples found in the genotypic and phenotypic tests were discussed in this study, and the presence of icaADC genes was observed in seven samples: six showed biofilm formation through the ABT technique and five through CRA. One sample showed biofilm formation only via the CRA method and did not present the icaADC genes. Samples were considered biofilm-producing only when icaAD or icaADC genes were detected ${ }^{8}$. We believe that tested samples were negative to CRA and positive to ABT and PCR (Table 1) due to the low specificity of the CRA technique. Research tests of biofilm formation reported in the literature have shown that between the ABT and CRA techniques, the latter is considered to be less specific when compared with the standard PCR methodology. We know that the role of the icaR gene is to regulate biofilm formation and that it may influence when present. The presence of only one of the icaABDC genes does not exclude the possibility of biofilm formation, perhaps to a lesser extent. Moreover, we must point out that phenotypic tests do not show $100 \%$ specificity and sensitivity.

The results have shown that the origin of the isolated bacterial species in PCs bags of this study is probably the skin. The phenotypic tests for the detection of biofilm production indicated good sensitivity and specificity when compared to the reference technique, particularly with the method of ABT that have shown high agreement. Thus, these results allow us to suggest this technique for the routine detection of CoNS strains able to produce biofilm in clinical microbiology laboratories. This is due to its easy application, low cost, high sensitivity and specificity, which ensure reliable results.

\section{ACKNOWLEDGMENTS}

The authors would like to thank the Blood Bank team of the city of Santa Maria, Rio Grande do Sul State (HEMORGS - SM, RS), especially the chemists Zanoni Segala and Viviane Ratzlaff. The authors would also like to express their gratitude to chemists of the Microbiology Laboratory at the University Hospital of Santa Maria (HUSM).

\section{CONFLICT OF INTEREST}

The authors declare that there are no conflicts of interest.

\section{REFERENCES}

1. Gomes EFP, Albiero AL. Transfusão de plaquetas. Manual de transfusão sanguínea. São Paulo: Roca; 2001. p.53-65.

2. Chang AH, Kirsch CM, Mobashery N, Johnson N, Levitt LJ. Streptococcus bovis septic shock due to contaminated transfused platelets. Am J Hematol. 2004;77:282-6.

3. Brasil. Ministério da Saúde. Caderno de informação: sangue e hemoderivados. Brasília: Ministério da Saúde; 2011

4. Brasil. Ministério da Saúde. Agência Nacional da Vigilância Sanitária. Relatório anual da avaliação sanitária dos serviços de hemoterapia. Brasília: Ministério da Saúde; 2012 .

5. Corash L. Bacterial contamination of platelet components: potential solutions to prevent transfusion-related sepsis. Expert Rev Hematol. 2011;4:509-25.

6. Brecher ME, Hay SN. Bacterial contamination of blood components. Clin Microbiol Rev. 2005;18:195-204

7. Larsen CP, Ezligini F, Hermansen NO, Kjeldsen-Kragh J. Six years' experience of using the BacT/ALERT system to screen all platelet concentrates, and additional testing of outdated platelet concentrates to estimate the frequency of false-negative results. Vox Sang. 2005;88: 93-7.

8. Oliveira A, Cunha MLRS. Comparasion of methods for the detection of biofilm production in coagulase-negative staphylococci. BMC Res Notes. 2010;3:260.

9. De Araújo GL, Coelho LR, De Carvalho CB, Maciel RM, Coronado AZ, Rozenbaum $\mathrm{R}$, et al. Commensal isolates of methicillin-resistant Staphylococcus epidermidis are also well equipped to produce biofilm on polystyrene surfaces. J Antimicrob Chemother. 2006;57:855-64

10. Rohde H, Burdelski C, Bartscht K, Hussain M, Buck F, Horstkotte MA, et al. Induction of Staphylococcus epidermidis biofilm formation via proteolytic processing of the accumulation-associated protein by staphylococcal and host proteases. Mol Microbiol. 2005;55:1883-95.

11. Vadyvaloo V, Otto M. Molecular genetics of Staphylococcus epidermidis biofilms on indwelling medical devices. Int J Artif Organs. 2005; 28:1069-78.

12. Costerton JW. Introduction to biofilm. Int J Antimicrob Agents. 1999;11:217-21.

13. Cafiso VT, Bertuccio T, Santagati M, Campanile F, Amicosante G, Perilli MG, et al Presence of the ica operon in clinical isolates of Staphylococcus epidermidis and its role in biofilm production. Clin Microbiol Infect. 2004;10:1081-8.

14. Mack D, Fischer W, Krokotsch A, Leopold K, Hartmann R, Egge H, et al. The intercellular adhesin involved in biofilm accumulation of Staphylococcus epidermidis is a linear beta-1,6-linked glucosaminoglycan: purification and structural analysis. J Bacteriol. 1996,178:175-83.

15. Morales M, Méndez-Alvarez S, Martín-López JV, Marrero C, Freytes CO. Biofilm: the microbial "bunker" for intravascular catheter-related infection. Support Care Cancer. 2004; 12:701-7.

16. Nilsdotter-Augustinsson A, Claesson C, Lindgren PE, Lundqvist-Gustafsson H, Öhman L. Adherence of Staphylococcus epidermidis to extracellular matrix proteins and effects of fibrinogen-bound bacteria on oxidase activity and apoptosis in neutrophils. APMIS, 2005; 113:361-73.

17. Gerke C, Kraft A, Süssmuth R, Schweitzer O, Götz F. Characterization of the $\mathrm{N}$-acetylglucosaminyltransferase activity involved in the biosynthesis of the Staphylococcus epidermidis polysaccharide intercellular adhesion. J Biol Chem. 1998;273:18586-93

18. Otto M. Staphylococcus epidermidis: the "accidental" pathogen. Nat Rev Microbiol. 2009; 7:555-67. 
Martini R, Hörner R, Rampelotto RF, Garzon LR, Nunes MS, Teixeira MD, Graichen DAS. Investigation of biofilm formation in coagulase-negative staphylococci isolated from platelet concentrate bags. Rev Inst Med Trop Sao Paulo. 2016;58:1.

19. Vuong C, Kocianova S, Voyich JM, Yao Y, Fischer ER, DeLeo FR, et al. A crucial role for exopolysaccharide modification in bacterial biofilm formation, immune evasion, and virulence. J Biol Chem. 2004;279:54881-6.

20. Dobinski S, Bartscht K, Mack D. Influence of Tn917 insertion of transcription of the icaADBC operon in six biofilm-negative transposon mutants of Staphylococcus epidermidis. Plasmid. 2002;47:10-7.

21. Gotz F. Staphylococcus and biofilms. Mol Microbiol. 2002;43:1367-78.

22. Von Eiff C, Peters G, Heilmann C. Pathogenesis of infections due to coagulasenegative staphylococci. Lancet Infect Dis. 2002;2:677-85

23. Heilmann C, Hussain M, Peters G, Gotz F. Evidence for autolysin-mediated primary attachment of Staphylococcus epidermidis to a polystyrene surface. Mol Microbiol. 1997;24: 1013-24.

24. Vuong C, Saenz HL, Gotz F, Otto M. Impact of the agr quorum-sensing system on adherence to polystyrene in Staphylococcus aureus. J Infect Dis. 2000;182:1688-93.

25. Mack D, Rohde H, Harris LG, Davies AP, Horstkotte MA, Knobloch JK. Biofilm formation in medical device-related infection. Int J Artif Organs. 2006;29:343-59.

26. Xu L, Li H, Vuong C, Vadyvaloo V, Wang J, Yao Y, et al. Role of the luxS quorumsensing system in biofilm formation and virulence of Staphylococcus epidermidis. Infect Immun. 2006;74:488-96.

27. Tormo MA, Knecht E, Götz F, Lasa I, Penadés JR. Bap-dependent biofilm formation by pathogenic species of Staphylococcus: evidence of horizontal gene transfer? Microbiology. 2005;151:2465-75.

28. Donlan RM. Biofilms: microbial life on surfaces. Emerg Infect Dis. 2002;8:881-90.

29. Cramton SE, Gotz F. Biofilm development in Staphylococcus. In: Ghannoum M, Ohlsen K, editors. Microbial biofilms. Washington: ASM Press; 2003. p.64-84.

30. Ali H, Greco-Stewart VS, Jacobs MR, Yomtovian RA, Rood IGH, De Korte D, et al. Characterization of the growth dynamics and biofilm formation of Staphylococcus epidermidis strains isolated from contaminated platelet units. J Med Microbiol. 2014;63 (Pt 6):884-91.

31. Martini R, Hörner R, Kempfer CB, Rodrigues MA, Gindri L, Tizotti MK, et al. Avaliação do desempenho de culturas convencionais na detecção da contaminação bacteriana em concentrados plaquetários em um hospital universitário do sul do Brasil. Rev Ciênc Farm Básica Apl. 2014;35:239-44.

32. Martini R, Hörner R, Rodrigues M de A, Kempfer CB, Tizotti MK, Ratzlaff V. Bacteriological analysis of platelets and cases of septic reactions associated with transfusion of contaminated samples. Transfus Apher Sci. 2012;47:313-8.

33. Cunha GS, Leão L, Pimenta F. Bacterial contamination of random-donor platelets in a university hospital in the midwestern region of Brazil. Transfusion. 2008;48:282-5.

34. Brasil. Ministério da Saúde. Agência Nacional de Vigilância Sanitária. Resolução da diretoria colegiada (RDC) $n^{\circ} 153$, de 13 de junho de 2004. Determina o regulamento técnico para os procedimentos hemoterápicos, incluindo a coleta, o processamento, a testagem, o armazenamento, o transporte, o controle de qualidade e o uso humano de sangue, e seus componentes, obtidos do sangue venoso, do cordão umbilical, da placenta e da medula óssea. Brasília: Diário Oficial da União. Seção 1, 24 de junho de 2004 .

35. Brasil. Ministério da Saúde. Agência Nacional de Vigilância Sanitária. Resolução da diretoria colegiada (RDC) $\mathrm{n}^{\circ} 57$, de 16 de dezembro de 2010. Determina o regulamento sanitário para serviços que desenvolvem atividades relacionadas ao ciclo produtivo do sangue humano e componentes e procedimentos transfusionais. Brasília: Diário Oficial da União, Poder Executivo. n 241 - Seção 1, 17 de dezembro de 2010.
36. Brasil. Ministério da Saúde. Agência Nacional de Vigilância Sanitária. Portaria n 2.712, de 12 de novembro de 2013. Redefine o regulamento técnico de procedimentos hemoterápicos. Brasília: Diário Oficial da União, Poder Executivo. Seção 1, 13 de novembro de 2013.

37. Yomtovian RA, Palavecino EL, Dysktra AH, Downes KA, Morrissey AM, Bajaksouzian S, et al. Evolution of surveillance methods for detection of bacteria contamination of platelets in a university hospital, 1991 through 2004. Transfusion. 2006;46:719-30

38. Aguilar MAP. Caracterização molecular da resistência aos carbapenêmicos em Enterobactérias isoladas em hospitais brasileiros (dissertação). São Paulo: Análises Clínicas, Universidade de São Paulo/ USP; 2009.

39. Freschi CR, Carvalho LFOS, Oliveira CJB. Comparison of DNA-extraction methods and selective enrichment broths on the detection of Salmonella typhimurium in swine feces by polymerase chain reaction (PCR). Braz J Microbiol. 2005;36:363-7.

40. Nogueira CAM, Momesso CAS, Machado RLD, De Almeida MTG, Rossit ARB Desempenho de kits comerciais e protocolos laboratoriais para a extração de DNA genômico bacteriano. Rev Panam Infectol. 2004;6:35-8.

41. Scheffer MC. Genotipagem e pesquisa de metalo-beta-lactamases em Isolados clínicos de Pseudomonas aeruginosa resistentes aos carbapenêmicos(dissertação). Curitiba: Microbiologia, Parasitologia e Patologia - Setor de Ciências Biológicas e da Saúde, Universidade Federal do Paraná; 2008.

42. Christensen GD, Simpson WA, Bisno AL, Beachey EH. Adherence of slime producing strains of Staphylococcus epidermidis to smooth surfaces. Infect Immun. 1982;37:318-

43. Freeman DJ, Falkiner FR, Keane CT. New method for detecting slime production by coagulase negative staphylococci. J Clin Pathol. 1989;42:872-4.

44. Arciola CR, Gamberini S, Campoccia D, Visai L, Speziale P, Baldassarri L. A multiplex PCR method for the detection of all five individual genes of ica locus in Staphylococcus epidermidis. A survey on 400 clinical isolates from prosthesisassociated infections. J Biomed Mater Res A. 2005;75:408-13.

45. Bonita R, Beaglehole R, Kjellström T. Epidemiologia básica. 2. ed. São Paulo: Ed Santos; 2010.

46. Hsueh JC, Ho CF, Chang SH, Pan FZ, Chen SC, Shi MD, et al. Blood surveillance and detection on platelet bacterial contamination associated with septic events. Transfus Med. 2009;19:350-6.

47. Martínez F, Tarrand J, Lichtiger B. Impact on patient outcome following transfusion of bacterially contaminated platelets: the M.D. Anderson Center experience.. Am J Clin Pathol. 2010;134:207-12.

48. Walther-Wenke G, Schrezenmeier H, Deitenbeck R, Geis G, Burkhart J, Höchsmann $\mathrm{B}$, et al. Screening of platelet concentrates for bacterial contamination: spectrum of bacteria detected, proportion of transfused units, and clinical follow-up. Ann Hematol. 2010;89:83-91.

49. Greco CA. Growth and biofilm formation by Staphylococcus epidermidis and other relevant contaminant bacteria during storage of platelet concentrates (tese). Ottawa: Faculty of Medicine, University of Ottawa; 2011.

50. Rood IGH, De Korte D, Ramírez-Arcos SM, Savelkoul PHM, Pettersson A. Distribution, origin and contamination risk of coagulase-negative staphylococci from platelet concentrates. J Med Microbiol. 2011;60(Pt 5):592-9.

51. Subramanian P, Shanmugam N, Sivaraman U, Kumar S, Selvaraj S. Antiobiotic resistance pattern of biofilm-forming uropathogens isolated from catheterised patients in Pondicherry, India. Australas Med J. 2012;5:344-8. 


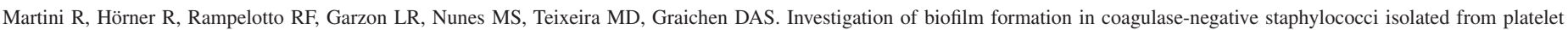
concentrate bags. Rev Inst Med Trop Sao Paulo. 2016;58:1.

52. Takeuchi F, Watanabe S, Baba T, Yuzawa H, Ito T, Morimoto Y, et al. Whole-genome sequencing of Staphylococcus haemolyticus uncovers the extreme plasticity of its genome and the evolution of human-colonizing staphylococcal species. J Bacteriol 2005; 187:7292-308

53. Chiew YF, Charles M, Johnstone MC, Thompson KM, Parnell KD, Penno EC. Detection of vancomycin heteroresistant Staphylococcus haemolyticus and vancomycin intermediate resistant Staphylococcus epidermidis by means of vancomycin screening agar. Pathology. 2007;39:375-7

54. Fredheim EGA, Klingenberg C, Rohde H, Frankenberger S, Gaustad P, Flaegstad T, et al. Biofilm Formation by Staphylococcus haemolyticus. J Clin Microbiol. 2009; $47: 1172-80$.

55. Arciola CR, Campoccia D, Gamberini G, Cervellati M, Donati E, Montanaro L. Detection of slime production by means of an optimized Congo red agar plate based on a colourimetric scale in Staphylococcus epidermidis clinical isolates genotyped for ica locus. Biomaterials. 2002;23:4233-9.
56. Lazzaratto C. Formação de biofilme de Staphylococcus epidermidis isolado de cateter venoso central através de métodos fenotípicos e genotípicos(dissertação). Porto Alegre: Faculdade de Medicina - Ciências Médicas, Universidade Federal do Rio Grande do Sul; 2010.

57. Ruzicka F, Holá V, Votava M, Tejkalová R, Horvát R, Heroldová M, et al. Biofilm detection and the clinical significance of Staphylococcus epidermidis isolates. Folia Microbiol(Praha). 2004:49:596-600.

58. Greco-Stewart VS, Brown EE, Parr C, Kalab M, Jacobs MR, Yomtovian RA, et al. Serratia marcescens strains implicated in adverse transfusion reactions form biofilms in platelet concentrates and demonstrate reduced detection by automated culture. Vox Sang. 2012;102:212-20.

Received: 02 December 2014

Accepted: 07 April 2015 